\title{
Nutritional Quality of the Walnut Male Inflorescences at Four Flowering Stages
}

\author{
Changlei Wang ${ }^{1,2}$, Wene Zhang ${ }^{1,2, *}$, Xuejun Pan ${ }^{1,2, *}$ \\ ${ }^{1}$ Guizhou Engineering Research Center for Fruit Crops, Guiyang, China \\ ${ }^{2}$ Agriculture College, Guizhou University, Guiyang, China \\ *Corresponding author: zhwene@aliyun.com, pxjun2050@aliyun.com
}

Received June 09, 2014; Revised July 24, 2014; Accepted August 04, 2014

\begin{abstract}
Nutrients, bioactive compounds and antioxidant activities of walnut male inflorescences at four flowering stages were analyzed in this study. The results showed that the male inflorescences were rich in carbohydrate, protein and mineral contents, and had antioxidant activities due to high contents of phenolic and flavonoid compounds. The nutritional compositions were varied at four stages. In the first half stage, including early flowering stage (EFS) and flowering stage (FS), the contents of protein, total amino acids, carbohydrates, antioxidants (phenolic, flavonoid and ascorbic acid) and some minerals (phosphorus, zinc and copper) were higher than that of the second half stage, including pollen-scattering stage (PSS) and later pollen-scattering stage (LPSS). Due to high contents of phenolic and flavonoid at EFS, the highest antioxidant activity was also observed at this stage. However, the higher amounts of crude fat, crude fiber and some mineral elements (potassium, iron, manganese, calcium and magnesium) were found in the second half stage. These results could contribute to using walnut male inflorescences as food, as well as developing new food products, and obtaining the bioactive substances from walnut male flowers.
\end{abstract}

Keywords: male inflorescences of walnut, proximate composition, minerals, amino acids, bioactive compounds, antioxidant activity

Cite This Article: Changlei Wang, Wene Zhang, and Xuejun Pan, "Nutritional Quality of the Walnut Male Inflorescences at Four Flowering Stages." Journal of Food and Nutrition Research, vol. 2, no. 8 (2014): 457-464. doi: 10.12691/jfnr-2-8-5.

\section{Introduction}

For centuries, flowers have been used for food in many parts of the world because they can increase and improve the appearance, taste and aesthetic value of foodstuffs [1]. Historically, for example the flowers of Magnolia denudata and Chrysanthemum morifolium have been used for more than two thousand years in China. In ancient Rome, flowers of roses were used for various kinds of purée and/or omelets. In medieval France, the flowers of calendula were used when preparing various salads. In Thailand, many flowers have been eaten since ancient time, and some have medicinal properties as well as nutritional value. Today, in addition to the aesthetic appearance, the specific taste and the smell of edible flowers, new data about their nutritive quality, especially about their high contents of bioactivity compounds, such as phenolic and flavonoid, have been a very important cause of an increasing interest for their consumption. Many studies indicated that edible flowers showed not only antioxidant and ROS scavenging activities but also had significant anti-inflammatory effects within the human body due to their bioactivity compounds. For instance, the flowers of ornamental roses were considered as a source of anti-inflammatory, anti-bacterial, anti- fungal and anti-viral substances [1,2]. The chrysanthemum flowers showed a marked antimicrobial, antiinflammatory, and inhibiting effect on carcinogenesis in mice [1].

Juglans had high content of bioactivity compounds, such as melatonin, serotonin and total phenols in nuts [3]. In addition to nuts, the other organs or parts, including green husk, root and leaves, also had the anti-diarrheic, anti-helmintic, anti-septic and astringent properties, and are widely used for traditional medicine to cure skin inflammations and ulcers [4]. There were some studies indicated that the flowers of walnut were good source of phenol, flavonoid and mineral contents [5,6] and showed remarkable antihypoxic, anti-inflammatory, antioxidant, antidepressant and antihemolytic activities in safe dose. Moreover, the hydroalcoholic extract of walnut male flowers could increase serum levels of insulin, and decrease blood glucose levels in diabetic rats [7]. In China, the male inflorescence of walnut was also known as longevity food, and a traditional vegetable in Minority Ethnic Area of Guizhou province and Yunnan Province. The walnut plantation areas were about 2,000 000 hectares in 2010 in China and every mature walnut tree had about 2 to $4 \mathrm{~kg}$ male flowers. In production, $95 \%$ male inflorescences should thin in order to save the tree nutrients and improve the fruit yield, which caused a large waste of natural antioxidant food resources. Moreover, in 
the pollen-scattering stage, a lot of pollen littered in the air and carried by wind, which could cause allergic reactions in people who were sensitive to it and they were manifested above all as sneezing and runny eyes even rash eczema. Therefore, using walnut male flower should not only benefit to save natural food resources, improve economic income, but also better for the environment. However, there was still lack of scientific information about the nutritional value of the male inflorescences of walnut, especial the species of $J$. According to Mlcek et al. [1], edible flowers were rich in common nutrients, bioactive compounds and had remarkable antioxidant activity, the objective of this study was to generate information about common nutritional components (proteins, fats, saccharides, minerals and vitamins ect.), the total phenolic and flavonoid contents and antioxidant properties of male flowers of $J$. sigillaia at four flower stages from southwest China and was expected to shed light on their potential health benefits that could be useful for consumers and public health workers.

\section{Material and Methods}

\subsection{Samples Preparation}

The experiment was performed at Guizhou Privincial Technology Research Center of Fruit Crop Engineering and Walnut Bureau of Hezhang from April of 2012 to September of 2013. Male inflorescences of walnut cultivar 'Qianhe-7' ( J. sigillata) were harvested from 36 year-old walnut tree in four different flower stages (early flowering stage, EFS; flowering stage, FS; pollen-scattering stage, PSS; later pollen-scattering stage, LPSS) at April in 2012. The evaluation criterion for the flower stage was made according to the method of Zhang [8]. The sample trees located in a southwest region of China (Hezhang County, Guizhou Province, 27.13 N, 104.71 E, 1750 m altitude, $13^{\circ} \mathrm{C}$ mean annual temperature, $835 \mathrm{~mm}$ total annual precipitation). After harvesting, male inflorescences were placed into an ice box and carried to the laboratory within 3-4 hrs. Then the samples were divided into two parts. One fresh sample were used for determination of ascorbic acid contents, the other samples were oven-dried at $50^{\circ} \mathrm{C}$ until a constant weight was obtained. Then the dry matters were obtained according to the method of Association of the Official Analytical Chemists [9]. The dry samples were ground and passed through a mesh sieve (40, meshes) for use.

\subsection{Reagents}

High-performance liquid chromatography (HPLC)grade methanol and acetonitrile, and analytically grade ethanol, octanol, perchloric acid, boric acid, anthrone, metaphosphate, metavanadate, dinitrophenol, oxalic acid, curcumin, strontium chloride and bromocresol green were all purchased from Sinopharm Chemical Reagent Co., Ltd (China). 2,4,6-tripiridyl-s-triazine (TPTZ), FolinCiocalteu reagent, amino acid standard and mineral standard were obtained from Sigma (St. Louis, MO, USA). Gallic acid and rutin were obtained from Fluka (Buchs, Switzerland). 2, 2-Diphenyl-1-picrylhydrazyl (DPPH) was purchased from Wako (Japan). All chemicals were analytically grade, unless otherwise noted. All aqueous solutions were prepared with ultrapure water purified with the Labpure Water Purification System (AKSW-24, Bedford, Chengdu, China).

\subsection{Methods}

\subsubsection{Proximate Analysis}

The ash content was calculated by incineration of the samples at $525^{\circ} \mathrm{C}$ for $4 \mathrm{~h}$ to a constant weight [9]. The total content of protein was calculated by multiplying the total nitrogen (Kjeldahl method) by 6.25 [9]. The fat content was determined by acid digestion prior to continuous extraction using petroleum ether in Soxtec system [9]. The contents of total soluble sugars and starch were analyzed using the method of anthrone colorimetry. The content of total dietary fiber was quantified following the acid-base scrubbing method [10]. The nonstructural carbohydrates were obtained by difference $\left(100-\sum\right.$ (protein + fat + ash + dietary fiber)), according to SánchezMachado et al. [11]. The available energy was calculated by multiplying the percent protein, fat and digestible carbohydrates by 4.0, 9.0 and 4.0, respectively and summing up the values. The values were reported as kilocalorie per $100 \mathrm{~g}$ on dry matter basis. All samples were analyzed three replicates.

\subsubsection{Mineral Analysis}

For determination the nitrogen $(\mathrm{N})$, potassium $(\mathrm{K})$ and phosphorous (P), $0.50 \mathrm{~g}$ oven dried power of sample was digested in flask with a $10 \mathrm{ml}$ of sulphuric acid. After complete digestion and cooling, the solution was diluted to $50 \mathrm{ml}$ with ultrapure water. The contents of $\mathrm{N}, \mathrm{K}$ and $\mathrm{P}$ were analyzed by Kjeldahl method, flame photometry method and spectrophotometric method, respectively. The total $\mathrm{N}$ content was expressed as crude protein. The contents of boron (B), calcium (Ca), iron (Fe), zinc (Zn), manganese $(\mathrm{Mn})$, copper $(\mathrm{Cu})$ and magnesium $(\mathrm{Mg})$ were analyzed according to the method of Association of the Official Analytical Chemists [9]. About $1.00 \mathrm{~g}$ of sample was incinerated in the muffle furnace (SX2-2.5-12, Boxun Industry \& Commerce Co., Ltd, Shanghai, China) for $4 \mathrm{~h}$. The ash was dissolved by hydrochloric acid $\left(6 \mathrm{~mol} \cdot \mathrm{L}^{-1}\right)$ and diluted to $50 \mathrm{ml}$ with ultrapure water. The content of $\mathrm{B}$ was measured by the means of spectrophotometric method. The contents of $\mathrm{Ca}, \mathrm{Fe}, \mathrm{Zn}, \mathrm{Mn}, \mathrm{Cu}$, and $\mathrm{Mg}$ were evaluated by atomic absorption spectrophotometer (TAS990, PERSEE, Beijing, China). All samples were analyzed five replicates.

\subsubsection{Amino Acids Analysis}

To determine the total content of the amino acids, an acid hydrolysis was performed on the proteins (500 mg of the sample was added with $10 \mathrm{ml}$ of $\mathrm{HCl}(6 \mathrm{M})$ and was heated at $110^{\circ} \mathrm{C}$ for $24 \mathrm{hrs}$ ). The hydrolyzed product was vacuumed and filtered, and then diluted to $50 \mathrm{ml}$ in a volumetric flask [11]. $2 \mathrm{~mL}$ solution was dried in oven at $60^{\circ} \mathrm{C}$; the residue was diluted with $2 \mathrm{ml}$ of borate buffer and agitated for 15 seconds, then filtered with a $0.45 \mu \mathrm{m}$ membrane. A $20 \mu \mathrm{L}$ sample of this solution was injected into the column of the automatic amino acid analyzer (A300, membrapure GmbH, Germany).

The automatic amino acid analytic system was equipped with an eluent unit, an autosampler, a main unit 
with a double piston pump, a rack for 2 glass bottles containing reagent and reactor washing solution, 2 photometers, a damping unit, a reactor, a separating column, a precolumn and a 2/3 way valve, an online solvent degasser, a chromatography data handling system. The amino acid analytic conditions were as follows: separation of the amino acid derivatives was achieved by a flow of $200 \mu \mathrm{L}$ per min at a column temperature of $40^{\circ} \mathrm{C}$. The reactor temperature was $115^{\circ} \mathrm{C}$. The presses of buffer and reagent were 60 bar and 7 bar, respectively. Amino acid samples were separated by ion exchange chromatography and determined by reaction with ninhydrin. The detection was by photometric detector using the wavelengths of emission at $570 \mathrm{~nm}$ (except proline at $440 \mathrm{~nm}$ ). All samples were analyzed three replicates.

The automatic amino acid analytic system allowed simultaneous analysis of 17 kinds of amino acids, and the different amino acids were identified by comparison with retention times for amino acid stock solutions. For determination of retention times, the reference standards were injected individually. The concentration of each amino acid was obtained by direct interpolation of the peak area in the correspondent linear calibration curve (peak area vs. concentration). These calibration curves were obtained over a wide concentration range in concordance with the level of each amino acid found in the samples that were analyzed. Three replications were done for amino acid determination.

\subsubsection{Bioactive Compounds Analysis}

\section{Determination of ascorbic acid (AsA)}

A high-performance liquid chromatographic (HPLC) method with ultraviolet detection was developed for determination of AsA [9,12]. $2.0 \mathrm{~g}$ of fresh sample was grounded with $7 \mathrm{ml}$ of metaphosphoric acid $(6 \%, \mathrm{w} / \mathrm{v})$ in a mortar. The homogenate was centrifuged at $10000 \mathrm{rpm}$ for 10 mins at $4^{\circ} \mathrm{C}$, the supernatant was collected and diluted to $50 \mathrm{ml}$ with ultrapure water. The solution was filtered with a membrane $0.45 \mu \mathrm{m}$ (Millipore) and then $20 \mu \mathrm{L}$ sample of it was injected into the column of the HLPC system.

The HLPC system (LC-15C, Shimadzu, Kyoto, Japan) was equipped with an autosampler (SIL-10AF), an online solvent degasser, a system controller with for chromatography data analysis, a pump (2LC-15C), a column oven (CTO-15C), and an UV detector (SPD-15C). Chromatographic analysis was performed using an analytical scale $(150 \times 4.6 \mathrm{~mm}$ i. d. $)$ and Alltima C18 column with a particle size of $5 \mu \mathrm{m}$ (Supelco, Bellefonte, PA). The HPLC conditions were as follows: The mobile phase was $0.2 \%(\mathrm{w} / \mathrm{v})$ metaphosphoric acid solution. The flow rate was constant at $1 \mathrm{ml}$ per min and the column was maintained at $30^{\circ} \mathrm{C}$. The detection was used the UV detector at the wavelengths of emission at $254 \mathrm{~nm}$.

\section{Determination of total phenolic content (TPC)}

For extraction of TPC, dried flower powder (1.5 g, $\mathrm{d}=0.0001 \mathrm{~g})$ was extracted with $60 \mathrm{ml}$ of methanol $(40 \%$, $\mathrm{v} / \mathrm{v}$ ) for $50 \mathrm{~min}$ at $50^{\circ} \mathrm{C}$ in ultrasonic cleaner and then filter. The TPC was estimated by a colorimetric assay described by Conde-Hernández et al. [13] with some modifications. The reaction mixture which consisted of
$0.5 \mathrm{ml}$ of the extracted solution, $5.0 \mathrm{ml}$ of FolinCiocalteau reagent and $15 \mathrm{ml} \mathrm{Na} \mathrm{CO}_{3}$ solution (20\%, w/v) was incubated at room temperature for $2 \mathrm{~h}$ in the dark and then diluted to $50 \mathrm{ml}$ with ultrapure water. The content of TPC was determined by measuring absorbance at $765 \mathrm{~nm}$, usinga UV-Vis spectro-photometer (UV-2550, Shimadzu, Kyoto, Japan). The TPC was expressed as mg gallic acid equivalent (GAE) per $100 \mathrm{~g}$ dry sample.

\section{Determination of total flavonoid content (TFC)}

The extraction of TFC was performed according to the method as described by Feng et al. [14] with minor modifications, dried flower powder $(0.5 \mathrm{~g}, \mathrm{~d}=0.0001 \mathrm{~g})$ was added with $30 \mathrm{ml}$ ethanol (30\%, v/v) and incubated for $1 \mathrm{~h}$ at $70^{\circ} \mathrm{C}$ in a water bath. The extracted production was filtered and the filtrate was used for TFC assay. The TFC was assayed by measuring the absorption at $510 \mathrm{~nm}$ in $3 \mathrm{ml}$ reaction mixture containing $0.8 \mathrm{ml}$ extract, $1.2 \mathrm{ml}$ ethanol $(30 \%, \mathrm{v} / \mathrm{v}), 0.5 \mathrm{ml} \mathrm{NaNO}_{2}$ solution $(5 \%, \mathrm{w} / \mathrm{v})$ and $0.5 \mathrm{ml}$ $\mathrm{Al}\left(\mathrm{NO}_{3}\right)_{3}$ solution $(10 \%$, w/v). The TFC was expressed as mg rutin equivalents (RE) per $100 \mathrm{~g}$ dry sample.

\subsubsection{Antioxidant Activity Analysis}

\section{DPPH radical-scavenging activity}

Dried flower powder (1.5 g, d=0.0001g) was extracted with $30 \mathrm{ml}$ of ethanol $(50 \%, \mathrm{v} / \mathrm{v})$ for $50 \mathrm{~min}$ at $50^{\circ} \mathrm{C}$ in ultrasonic cleaner and then filtered. The filter was used for assay the antioxidant activity. The scavenging activity of the stable 1, 1-diphenyl-2-picrylhydrazyl (DPPH) radical was determined according to the method described by Motamed et al. [15] with a slight modification. Briefly, 2 ml DPPH ethanol solution $(0.2 \mathrm{mM})$ was prepared and mixed with $2 \mathrm{ml}$ sample ethanol solution. The mixture was incubated for $30 \mathrm{~min}$ at room temperature and measured the absorbance at $517 \mathrm{~nm}$. The DPPH solution without sample and AsA ethanol solution were used as control and standard, respectively. The activity of radicalscavenging was given as \% DPPH radical scavenging that was calculated by the equation: \% DPPH radical scavenging $=$ (control absorbance - sample absorbance)/control absorbance $* 100$.

\section{Ferric reducing ability of plasma (FRAP)}

FRAP assay is a simple, reproducible, rapid, and inexpensive method that measures reductive ability of antiradical and it is evaluated by the transformation of $\mathrm{Fe}^{3+}$-TPTZ to a blue color $\mathrm{Fe}^{2+}-\mathrm{TPTZ}$, as a measure of total antioxidant capacity [16]. The FRAP reagent contained of $2.5 \mathrm{ml}$ of TPTZ $\left(10 \mathrm{mmolL}^{-1}\right)$ dissolved in 40 $\mathrm{mmolL}^{-1} \mathrm{HCl}, 2.5 \mathrm{ml}$ of $\mathrm{FeCl}_{3} \cdot 6 \mathrm{H}_{2} \mathrm{O}\left(20 \mathrm{mmolL}^{-1}\right)$ and 25 $\mathrm{ml}$ of acetate buffer $\left(0.3 \mathrm{mmolL}^{-1}, \mathrm{pH}\right.$ 3.6). The antioxidant potential of the extract was determined against standard curve of $\mathrm{FeSO}_{4}(0,25,50,100,200,400$, and $\left.800 \mu \mathrm{molL}^{-1}\right)$ in $0.1 \%(\mathrm{v} / \mathrm{v}) \mathrm{HCl}$. Briefly, $2.7 \mathrm{ml}$ of FRAP reagent, prepared freshly and warmed at $37^{\circ} \mathrm{C}$, mixed with $0.3 \mathrm{ml}$ of sample solution was used to measure the absorbance at $593 \mathrm{~nm}$, methanol as the reagent blank.. The FRAP was expressed as mmol $\mathrm{FeSO}_{4}$ per $100 \mathrm{~g}$ DW.

\subsection{Statistical Analysis}

Data was processed with the statistics package SPSS 12.0 for Windows (SPSS Inc., Chicago, IL, USA) which 
analyzed the average and the standard deviation of repetitions.

\section{Results and Discussion}

\subsection{Proximate Composition}

The proximate compositions of walnut male inflorescences in four different stages were shown in Table 1. The dry matter of the male inflorescences in

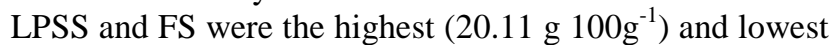
(14.56 g $\left.100 \mathrm{~g}^{-1}\right)$, respectively. There were no significant differences in the dry matter of the first two stages. Dry matter content of walnut male flowers was relatively high as a kind of vegetable, and was mainly composed of carbohydrates, proteins, fiber and fats (Table 1). From EFS to LPSS, the ash content showed an increase trend,

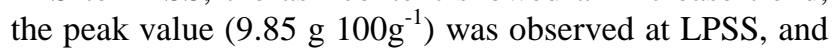
these values also indicated that the walnut male flower contained some nutritionally important minerals required by the body. A high crude protein content was found in the walnut male inflorescences and it was in the range of

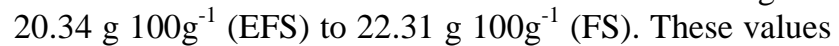
were similar to that presented by Chen et al. [17] of 21.23 $\mathrm{g} 100 \mathrm{~g}^{-1}$ and higher than that determined in the walnut (15 g $100 \mathrm{~g}^{-1}$ ). Moreover, the protein contents of walnut male flowers also could be comparable with peanut kernels (25-

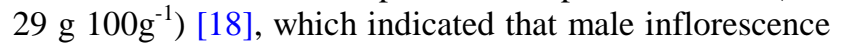
could be considered as a good source of protein. With the extension of flower time, the protein content decreased at PSS and LPSS, which might be due to the high protein content in pollen [19]. The highest crude fiber content

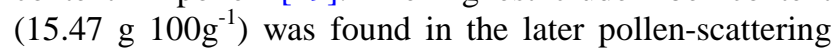
stage, and there were no significant differences among EFS, FS and PSS. These data showed that the crude fiber contents of walnut male flower (2.03-3.11 g $100 \mathrm{~g}^{-1}$, converted into fresh weight) were higher than those determined in some kinds of vegetable species, such as

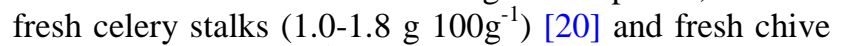

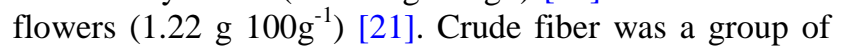
indigestible carbohydrates. For human, it could improve the function of the alimentary tract and also lower blood glucose and cholesterol levels [22]. The content of crude fat and total sugars all increased firstly and then decreased from EFS to LPSS and the highest contents were noted at

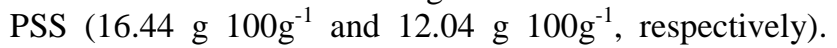
And fat was involved in the insulation of body organs and in the maintenance of body temperature and cell function. Additionally, fats were sources of omega-3 and omega-6 fatty acids and were required for the digestion, absorption, and transport of vitamins A, D, E, and K. While the peak value of starch $\left(0.98 \mathrm{~g}_{100 \mathrm{~g}^{-1}}\right)$ was found at FS. An increase in sugars from EFS to PSS might be due to accumulation of more sugars due to hydrolysis of starch and slight decline at LPSS was due to utilization of sugars respiration process.

The content of carbohydrates was more than $40 \%$ in the dry flower sample and that of EFS was the highest (47.54 g $\left.100 \mathrm{~g}^{-1}\right)$. High carbohydrates percent in food could provide energy for human, which enabled cells to do all of their functions, including building protein's and others substances needed by the body [23]. According to the relationship of coefficient conversion, the available energy was ranging from 469.18 (LPSS) to $484.79 \mathrm{kcal}$ (FS) in $100 \mathrm{~g}$ dry flower sample. The consumption of $100 \mathrm{~g}$ of this sample would provide energy intake from $23.46 \%$ to $24.24 \%$ in a standard daily diet of $2000 \mathrm{kcal}$, which indicated that male inflorescence was a good source of available energy.

Table 1. Proximate compositions of walnut male inflorescence at four flower stages

\begin{tabular}{|c|c|c|c|c|}
\hline Nutrients & EFS & FS & PSS & LPSS \\
\hline $\begin{array}{c}\text { Dry matter } \\
\left(\mathrm{g} 100 \mathrm{~g}^{-1} \mathrm{FW}\right)\end{array}$ & $14.56 \pm 0.68 b$ & $14.56 \pm 0.20 \mathrm{~b}$ & $18.65 \pm 5.24 \mathrm{ab}$ & $20.11 \pm 1.6 a$ \\
\hline $\begin{array}{c}\text { Protein } \\
\left.\text { (g } 100 \mathrm{~g}^{-1} \mathrm{DW}\right)\end{array}$ & $20.34 \pm 0.20 d$ & $22.31 \pm 0.44 a$ & $21.01 \pm 0.09 c$ & $21.72 \pm 0.25 b$ \\
\hline $\begin{array}{c}\text { Ash } \\
\text { (g } 100 g^{-1} \text { DW) }\end{array}$ & $5.99 \pm 0.48 d$ & $6.66 \pm 0.29 \mathrm{c}$ & $6.61 \pm 0.09 b$ & $9.85 \pm 0.08 \mathrm{a}$ \\
\hline $\begin{array}{c}\text { Fat } \\
\left(\mathrm{g} 100 \mathrm{~g}^{-1} \mathrm{DW}\right)\end{array}$ & $12.19 \pm 0.19 \mathrm{c}$ & $14.92 \pm 0.73 b$ & $16.44 \pm 1.23 a$ & $8.05 \pm 0.28 \mathrm{~d}$ \\
\hline $\begin{array}{l}\text { Carbohydrates } \\
\left(\mathrm{g} 100 \mathrm{~g}^{-1} \mathrm{DW}\right)\end{array}$ & $47.54 \pm 0.36 a$ & $41.98 \pm 0.68 \mathrm{c}$ & $42.20 \pm 1.01 \mathrm{c}$ & $44.92 \pm 0.57 b$ \\
\hline Total soluble & 11 r $19+0.16$ & $1171+0.05 \mathrm{~b}$ & $1204+010$ & $1128+016$ \\
\hline $\begin{array}{l}\text { Sugar } \\
\left.\text { (g } 100 g^{-1} \mathrm{DW}\right)\end{array}$ & $11.1 J \pm 0.100$ & $11.71 \pm 0.050$ & $12.04 \pm 0.10 \mathrm{~d}$ & $11.28 \pm 0.10 \mathrm{C}$ \\
\hline $\begin{array}{l}\text { Crude fiber } \\
\text { (g } 100 \mathrm{~g}^{-1} \mathrm{DW} \text { ) }\end{array}$ & $13.94 \pm 0.09 b$ & $14.14 \pm 0.14 b$ & $13.74 \pm 0.28 b$ & $15.47 \pm 0.19 a$ \\
\hline $\begin{array}{c}\text { Starch } \\
\left.\text { (g } 100 \mathrm{~g}^{-1} \mathrm{DW}\right)\end{array}$ & $0.72 \pm 0.04 b$ & $0.98 \pm 0.09 a$ & $0.48 \pm 0.06 \mathrm{c}$ & $0.46 \pm 0.02 c$ \\
\hline $\begin{array}{c}\text { Available } \\
\text { energy } \\
\text { (Kcal 100g-1 } \\
\text { DW) }\end{array}$ & $477.74 \pm 2.85 b$ & $484.79 \pm 3.43 a$ & $478.61 \pm 0.76 b$ & $469.18 \pm 1.52 \mathrm{c}$ \\
\hline
\end{tabular}

\subsection{Mineral Composition}

As shown in Table 2 and Table 3, among all mineral elements, the contents of potassium (from 27.16 to 38.38 $\mathrm{g} \mathrm{kg}^{-1} \mathrm{DW}$ ) were the highest, followed by phosphorus ( 3.48 to $4.89 \mathrm{~g} \mathrm{~kg}^{-1} \mathrm{DW}$ ), calcium (2.73 to $7.05 \mathrm{~g} \mathrm{~kg}^{-1} \mathrm{DW}$ ) and magnesium (2.29 to $\left.2.95 \mathrm{~g} \mathrm{~kg}^{-1} \mathrm{DW}\right)$. In all micronutrients, the highest contents were found in iron elements (315.63 to $688.21 \mathrm{mg} \mathrm{kg}^{-1} \mathrm{DW}$ ), followed by manganese (113.45 to $214.85 \mathrm{mg} \mathrm{kg}^{-1} \mathrm{DW}$ ), zinc (49.76 to $74.86 \mathrm{mg} \mathrm{kg}^{-1} \mathrm{DW}$ ) and boron (22.77 to $28.61 \mathrm{mg} \mathrm{kg}^{-1}$ DW). The content of copper (19.80 to $23.95 \mathrm{mg} \mathrm{kg}^{-1} \mathrm{DW}$ ) was the lowest. Among four flowering stages, the highest contents of phosphorus, zinc, copper and boron were found at FS, where as the highest potassium, calcium, magnesium, iron and manganese at LPSS. These results showed that the mineral contents of walnut male flower, especially the micronutrients, were similar to or above those determined in some kinds of vegetable species including carrot and cauliflower that the contents of manganese, copper and zinc were 18 and $56 \mathrm{mg} \mathrm{kg}^{-1} \mathrm{DW}$, 8 and $15 \mathrm{mg} \mathrm{kg}^{-1} \mathrm{DW}, 32$ and $47 \mathrm{mg} \mathrm{kg}^{-1} \mathrm{DW}$, respectively [24]. Minerals accounted for $4.7 \%$ of the weight of the human organism. Most of the minerals were salts containing calcium and phosphorus, as the building blocks of the human skeleton [25]. According to Shajib et al. [26], the daily iron, zinc and copper requirements of an adult man were 10 to $15 \mathrm{mg}$ per day, 12 to $15 \mathrm{mg}$ per day and 2 to $3 \mathrm{mg}$ per day. Our results indicated that the male inflorescences of walnut, to some extent, can meet the daily requirement of these minerals. Furthermore, many of minerals were the fundamental part of enzyme systems and served as the prevention of many diseases and strengthened the human immune system [1,27]. The present study suggested that there were higher mineral 
contents in male inflorescences of walnut, which might be one of the causes of anti-inflammatory effect of walnut flowers [5].

Table 2. Contents of macronutrients of male inflorescence of $J$. sigillaia at four flower stages

\begin{tabular}{ccccc}
\hline Stages & $\begin{array}{c}\text { Phosphorus } \\
/ \mathrm{g} \mathrm{kg}^{-1}\end{array}$ & $\begin{array}{c}\text { Potassium } \\
/ \mathrm{g} \mathrm{kg}^{-1}\end{array}$ & $\begin{array}{c}\text { Calcium } \\
/ \mathrm{g} \mathrm{kg}^{-1}\end{array}$ & $\begin{array}{c}\text { Magnesium } \\
/ \mathrm{g} \mathrm{kg}^{-1}\end{array}$ \\
\hline EFS & $3.95 \pm 0.26 \mathrm{~b}$ & $27.16 \pm 0.17 \mathrm{~d}$ & $2.95 \pm 0.05 \mathrm{bc}$ & $2.39 \pm 0.07 \mathrm{bc}$ \\
FS & $4.89 \pm 0.24 \mathrm{a}$ & $28.76 \pm 0.16 \mathrm{~b}$ & $2.73 \pm 0.167 \mathrm{c}$ & $2.46 \pm 0.08 \mathrm{~b}$ \\
PSS & $4.13 \pm 0.10 \mathrm{~b}$ & $27.75 \pm 0.62 \mathrm{c}$ & $3.04 \pm 0.04 \mathrm{~b}$ & $2.29 \pm 0.07 \mathrm{c}$ \\
LPSS & $3.48 \pm 0.14 \mathrm{c}$ & $38.38 \pm 0.44 \mathrm{a}$ & $7.05 \pm 0.18 \mathrm{a}$ & $2.95 \pm 0.03 \mathrm{a}$ \\
\hline
\end{tabular}

Mean value \pm standard deviation $(n=5$, by duplicate). Different low letters in each row indicate the significant difference among four flower stages at $p<0.05$.

Table 3. Contents of micronutrients of walnut male inflorescence of J. sigillaia at four flower stages

\begin{tabular}{cccccc}
\hline Stages & $\begin{array}{c}\text { Iron } \\
/ \mathrm{mg} \mathrm{kg}^{-1}\end{array}$ & $\begin{array}{c}\text { Manganese } \\
/ \mathrm{mg} \mathrm{kg}^{-1}\end{array}$ & $\begin{array}{c}\text { Copper } \\
/ \mathrm{mg} \mathrm{kg}^{-1}\end{array}$ & $\begin{array}{c}\text { Zinc } \\
/ \mathrm{mg} \mathrm{kg}^{-1}\end{array}$ & $\begin{array}{c}\text { Boron } \\
/ \mathrm{mg} \mathrm{kg}^{-1}\end{array}$ \\
\hline EFS & $318.67 \pm 30.68 \mathrm{~b}$ & $113.45 \pm 2.28 \mathrm{c}$ & $20.77 \pm 0.30 \mathrm{~b}$ & $49.76 \pm 2.24 \mathrm{c}$ & $22.77 \pm 1.04 \mathrm{c}$ \\
FS & $351.62 \pm 3.47 \mathrm{~b}$ & $128.06 \pm 4.37 \mathrm{~b}$ & $23.95 \pm 0.38 \mathrm{a}$ & $74.86 \pm 1.60 \mathrm{a}$ & $28.61 \pm 0.55 \mathrm{a}$ \\
PSS & $315.63 \pm 20.35 \mathrm{~b}$ & $115.46 \pm 5.39 \mathrm{c}$ & $19.80 \pm 0.35 \mathrm{c}$ & $53.17 \pm 0.50 \mathrm{~b}$ & $25.89 \pm 0.11 \mathrm{~b}$ \\
LPSS & $688.21 \pm 24.16 \mathrm{a}$ & $214.85 \pm 0.45 \mathrm{a}$ & $23.51 \pm 0.18 \mathrm{a}$ & $53.71 \pm 1.70 \mathrm{~b}$ & $23.70 \pm 1.03 \mathrm{c}$
\end{tabular}

Mean value + standard deviation ( $\mathrm{n}=5$, by duplicate). Different low letters in each row indicate the significant difference among four flower stages at $p<0.05$.

Table 4. Contents of amino acids $\left(\mathrm{g} 100 \mathrm{~g}^{-1} \mathrm{DW}\right)$ at four different stages of walnut male inflorescences

\begin{tabular}{|c|c|c|c|c|}
\hline Amino acids & EFS & FS & PSS & LPSS \\
\hline Aspartic acid & $1.34 \pm 0.02 b$ & $1.41 \pm 0.03 a$ & $1.38 \pm 0.01 \mathrm{a}$ & $1.21 \pm 0.02 \mathrm{c}$ \\
\hline Threonine $^{\mathrm{z}}$ & $0.65 \pm 0.04 a$ & $0.69 \pm 0.01 \mathrm{a}$ & $0.68 \pm 0.01 \mathrm{a}$ & $0.57 \pm 0.01 b$ \\
\hline Serine & $0.79 \pm 0.01 \mathrm{a}$ & $0.81 \pm 0.03 a$ & $0.81 \pm 0.01 \mathrm{a}$ & $0.66 \pm 0.03 \mathrm{~b}$ \\
\hline Glutamic acid & $1.68 \pm 0.04 \mathrm{c}$ & $1.95 \pm 0.05 a$ & $2.01 \pm 0.01 \mathrm{a}$ & $1.87 \pm 0.02 b$ \\
\hline Glycine & $0.70 \pm 0.03 b$ & $0.77 \pm 0.01 \mathrm{a}$ & $0.72 \pm 0.01 b$ & $0.61 \pm 0.04 \mathrm{c}$ \\
\hline Alanine & $0.81 \pm 0.03 b$ & $0.86 \pm 0.01 \mathrm{a}$ & $0.83 \pm 0.01 b$ & $0.75 \pm 0.02 \mathrm{c}$ \\
\hline Cysteine & $0.06 \pm 0.01 \mathrm{a}$ & $0.04 \pm 0.00 \mathrm{bc}$ & $0.03 \pm 0.00 \mathrm{c}$ & $0.04 \pm 0.00 \mathrm{~b}$ \\
\hline Valine ${ }^{\mathrm{z}}$ & $0.67 \pm 0.03 \mathrm{ab}$ & $0.71 \pm 0.02 \mathrm{a}$ & $0.63 \pm 0.02 b$ & $0.59 \pm 0.01 \mathrm{c}$ \\
\hline Methionine $^{\mathrm{z}}$ & $0.21 \pm 0.01 \mathrm{a}$ & $0.15 \pm 0.01 b$ & $0.20 \pm 0.00 a$ & $0.15 \pm 0.01 b$ \\
\hline Isoleucine $\mathrm{z}^{\mathrm{z}}$ & $0.63 \pm 0.02 \mathrm{a}$ & $0.60 \pm 0.01 b$ & $0.59 \pm 0.01 b$ & $0.49 \pm 0.01 \mathrm{c}$ \\
\hline Leucine $^{\mathrm{z}}$ & $1.10 \pm 0.02 b$ & $1.16 \pm 0.03 a$ & $1.16 \pm 0.03 \mathrm{a}$ & $0.95 \pm 0.02 \mathrm{c}$ \\
\hline Tyrosine & $0.45 \pm 0.06 \mathrm{a}$ & $0.41 \pm 0.01 \mathrm{ab}$ & $0.38 \pm 0.01 b$ & $0.32 \pm 0.01 \mathrm{c}$ \\
\hline Phenylalanine $^{\mathrm{z}}$ & $0.84 \pm 0.04 b$ & $0.88 \pm 0.02 \mathrm{ab}$ & $0.92 \pm 0.01 a$ & $0.73 \pm 0.01 \mathrm{c}$ \\
\hline Histidine $\mathrm{z}^{\mathrm{z}}$ & $0.45 \pm 0.02 \mathrm{a}$ & $0.37 \pm 0.03 b$ & $0.30 \pm 0.00 \mathrm{c}$ & $0.28 \pm 0.01 \mathrm{c}$ \\
\hline Lysine $^{\mathrm{z}}$ & $0.61 \pm 0.01 b$ & $0.65 \pm 0.01 \mathrm{a}$ & $0.64 \pm 0.02 \mathrm{a}$ & $0.48 \pm 0.01 \mathrm{c}$ \\
\hline Arginine $^{\mathrm{z}}$ & $1.24 \pm 0.02 b$ & $1.33 \pm 0.04 \mathrm{a}$ & $1.20 \pm 0.02 b c$ & $1.18 \pm 0.01 \mathrm{c}$ \\
\hline Proline & $0.69 \pm 0.05 a$ & $0.64 \pm 0.01 \mathrm{a}$ & $0.65 \pm 0.03 a$ & $0.27 \pm 0.02 b$ \\
\hline EAA & $6.40 \pm 0.07 \mathrm{ab}$ & $6.54 \pm 0.13 a$ & $6.32 \pm 0.01 b$ & $5.42 \pm 0.06 c$ \\
\hline TAA & $12.92 \pm 0.05 b$ & $13.43 \pm 0.24 a$ & $13.13 \pm 0.01 b$ & $11.15 \pm 0.17 \mathrm{c}$ \\
\hline $\begin{array}{c}\mathrm{EAA} / \mathrm{TAA} \\
(\%)\end{array}$ & 49.54 & 48.70 & 48.13 & 48.61 \\
\hline
\end{tabular}

Mean value \pm standard deviation $(\mathrm{n}=3$, by duplicate). Different low letters in each line indicate the significant difference among four flower stages at $p<0.05$.

${ }^{\mathrm{z}}$ Essential amino acid, EAA: essential amino acids. TAA: total amino acids.

\subsection{Amino Acid}

As shown in Table 4, the male inflorescence of walnut was rich in 17 kinds of amino acids; the tryptophan was not detected because it was completely destroyed by acid hydrolysis. The contents of total amino acids ranged from

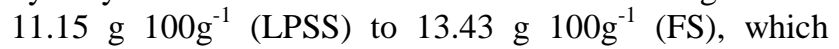
contained 9 kinds of essential amino acids (including the semi-essential amino acids, arginine and histidine). The

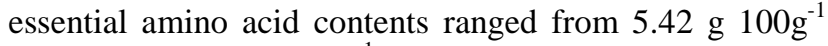

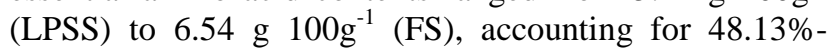
$49.54 \%$ of total amino acids. Both total amino acid and essential amino acid contents of FS were higher than those in the other stages. The amino acids which were concentrated in a higher proportion in the different stages were glutamic acid, aspartic acid, arginine and leucine,

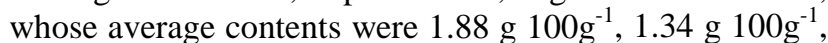

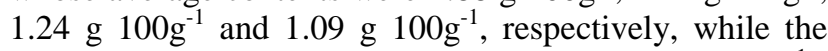

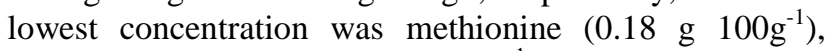

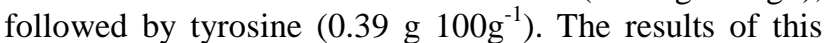
study showed that the amino acids contents in walnut male inflorescence were comparable to or higher than that in walnut kernels, whose contents of arginine, glutamic acid,

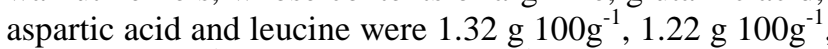

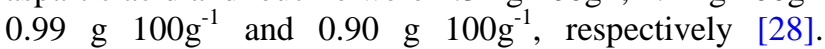
According to WHO/FAO [29], the EAA/TAA of high quality protein was more than $36 \%$, and the EAA/TAA of walnut male inflorescence were all above $48 \%$, therefore, the protein in the walnut male inflorescences could be considered as a kind of high-quality protein.

\subsection{Bioactive Compounds}

\subsubsection{Ascorbic Acid Content}

In this study, the ascorbic acid contents (AsA) of male inflorescences in different stages were shown in Table 5. Among four flowering stages, the highest content of AsA

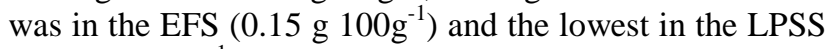

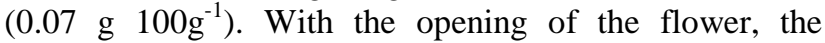
content of AsA showed a decline trend which may be due to reducing of synthesis and increasing of decomposition. These values showed that the AsA contents of walnut male flower were comparable to or higher than those determined in the some kinds of fruits, such as kiwifruit

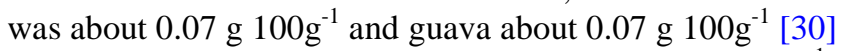

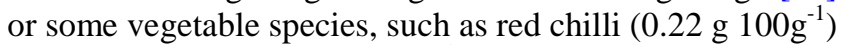

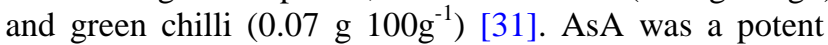
water-soluble antioxidant in humans and its antioxidant effects had been demonstrated in many experiments in vitro [32]. Shajib et al. [26] reported that the minimum daily requirement of AsA for preventing clinical symptoms of the scurvy for an adult was about $10 \mathrm{mg}$ or little less. In the present study, there was more than $10 \mathrm{mg}$ AsA per $100 \mathrm{~g}$ walnut male flower. Therefore, we could conclude that daily intake of $100 \mathrm{~g}$ walnut male flower could prevent scurvy and the male inflorescences might be considered as a good source of AsA.

\subsubsection{Total Phenolic Content (TPC)}

The TPC were presented in Table 5. There were significant differences among different stages tested. The TPC of walnut male inflorescences ranged from 2.13 to

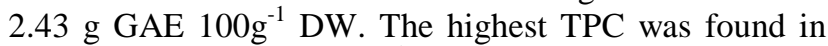
the EFS (2.43 $\left.\mathrm{g} \mathrm{GAE} 100 \mathrm{~g}^{-1} \mathrm{DW}\right)$, followed by FS (2.27 $\mathrm{g}$ GAE $\left.100 \mathrm{~g}^{-1} \mathrm{DW}\right)$ and PSS (2.21 g GAE $\left.100 \mathrm{~g}^{-1} \mathrm{DW}\right)$, while in the LPSS, the male inflorescence had the lowest TPC (2.13 g GAE $\left.100 \mathrm{~g}^{-1} \mathrm{DW}\right)$. It was lower than the content obtained by Nabavi et al. [5] in J. regia flower

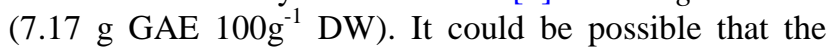
variations in the TPC of walnut flowers were influenced by the environmental conditions of growing fields and the species. However, the TPC of walnut male flower in this 
study was higher than that of walnut kernels (1.25 g GAE $100 \mathrm{~g}^{-1} \mathrm{DW}$ ) [33]. Furthermore, these values (0.33 to 0.43 g GAE $100 \mathrm{~g}^{-1} \mathrm{FW}$ ) were comparable to or slightly lower than those determined in the some kinds of edible flowers,

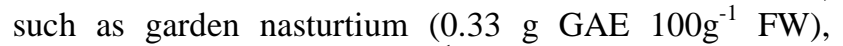
cornflower (0.48 g GAE $\left.100 \mathrm{~g}^{-1} \mathrm{FW}\right)$ and begonias (0.49 $\mathrm{g}$ GAE $100 \mathrm{~g}^{-1} \mathrm{FW}$ ) [2]. The TPC have been reported to be associated with antioxidant activity, which potentially had beneficial implications in human health [34]. Some reporters found that walnut flowers had remarkable pharmacological effects [5] and antihemolytic activity [6] both attributed to high phenol and flavonoid contents. Our study also proved that there were high TPC in the walnut male flower, which was accordance with the results of Nabavi et al [5].

\subsubsection{Total Flavonoid Content (TFC)}

The TFC of walnut male flowers had significant differences among four flowering stages (Table 5). In the FS, the male inflorescences of walnut had the highest TFC with a concentration of $2.15 \mathrm{~g}$ RE $100 \mathrm{~g}^{-1} \mathrm{DW}$, followed by the EFS (2.06 g RE $\left.100 \mathrm{~g}^{-1} \mathrm{DW}\right)$ and the PSS (1.70 g RE $\left.100 \mathrm{~g}^{-1} \mathrm{DW}\right)$. The lowest TFC was observed in the LPSS, which was of $1.44 \mathrm{~g} \mathrm{RE} 100 \mathrm{~g}^{-1} \mathrm{DW}$. Our results suggested that the TFC in walnut male inflorescences $(0.29$ to $0.32 \mathrm{~g}$ RE $100 \mathrm{~g}^{-1} \mathrm{FW}$ ) was higher than those determined in the some kinds of edible flowers, such as garden nasturtium (0.14 g RE $\left.100 \mathrm{~g}^{-1} \mathrm{FW}\right)$, violet $\left(0.20 \mathrm{~g} \mathrm{RE} 100 \mathrm{~g}^{-1} \mathrm{FW}\right)$ and carnation ( 0.23 g RE $\left.100 \mathrm{~g}^{-1} \mathrm{FW}\right)$ [2]. Previous works also indicated that yellow flowers had high the flavonoid content [34] and especially the pollen was rich in it, while the phenolic substances mainly existed in nectar [1]. According to results of TPC and TFC, it was found that the peaks of TPC and TFC were not appeared at the same flower opening stage, the TPC reached peak at the EFS, however, the peak of TFC was six days later than that of TPC and at FS, when the appearance of inflorescence was yellow. The reason might be associated with high content pollen at flowering stage. So we could deduce that the contents and types of antioxidant were varied with the opening of flower and the antioxidant effect might be different due to these causes. For humans, several health beneficial properties of dietary flavonoids were recognized for their antioxidant and antiproliferative effects which might protect the body from various diseases, such as cancers, cardiovascular disease and inflammatory [35]. Nabavi et al. [5] also found walnut flowers had antihypoxic activity and antidepressant activity effect due to the high content of flavonoids (6.17 $\left.\mathrm{g} \mathrm{RE} 100 \mathrm{~g}^{-1} \mathrm{DW}\right)$.

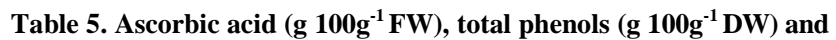
total flavonoid (g $100 \mathrm{~g}^{-1} \mathrm{DW}$ ) content of male inflorescence of $J$. sigillaia at four flower stages

\begin{tabular}{ccccc}
\hline $\begin{array}{c}\text { Bioactive } \\
\text { compounds }\end{array}$ & EFS & FS & PSS & LPSS \\
\hline $\begin{array}{c}\text { Ascorbic acid } \\
\left(\mathrm{g} 100 \mathrm{~g}^{-1} \mathrm{FW}\right)\end{array}$ & $0.15 \pm 0.01 \mathrm{a}$ & $0.09 \pm 0.01 \mathrm{~b}$ & $0.09 \pm 0.01 \mathrm{~b}$ & $0.07 \pm 0.01 \mathrm{c}$ \\
$\begin{array}{c}\text { Total phenols } \\
\left(\mathrm{g} 100 \mathrm{~g}^{-1} \mathrm{DW}\right)\end{array}$ & $2.43 \pm 0.05 \mathrm{a}$ & $2.26 \pm 0.02 \mathrm{~b}$ & $2.21 \pm 0.01 \mathrm{c}$ & $2.13 \pm 0.02 \mathrm{~d}$ \\
$\begin{array}{c}\text { Total flavonoid (g } \\
\left.100 \mathrm{~g}^{-1} \mathrm{DW}\right)\end{array}$ & $2.06 \pm 0.02 \mathrm{~b}$ & $2.15 \pm 0.04 \mathrm{a}$ & $1.70 \pm 0.04 \mathrm{c}$ & $1.44 \pm 0.04 \mathrm{~d}$ \\
\hline
\end{tabular}

Mean value \pm standard deviation $(n=3$, by duplicate). Different low letters in each line indicate the significant difference among four flower stages at $p<0.05$.

\subsection{Antioxidant Activity}

\subsubsection{DPPH Radical-Scavenging Activity}

The DPPH radical-scavenging activity (percentage inhibition) of the male inflorescences extracts was given in Table 6. DPPH radical scavenging capacity of extracts ranged from $84.33 \%$ (EFS) to $79.26 \%$ (LPSS) and showed a trend of decline with the opening of flower. Significant differences were detected among four flower stages. The $\mathrm{DPPH}$ assay was a preliminary test to investigate the antioxidant potential of extracts [34]. Results showed that the DPPH radical-scavenging activity of walnut male flowers was higher than those determined in some kinds of edible flowers, such as Queen of tropic flower (31.39\%), West Indian jasmine (62.52\%) and pagoda tree $(69.65 \%)$ [34]. The results were in agreement with previous works that the walnut male flowers had remarkable antioxidant activity reported by Nabavi et al. [5].

\subsubsection{Ferric Reducing Ability of Plasma (FRAP) Assay}

Among four flowering stages, the highest FRAP activity was observed at the EFS (2.06 mmol $\mathrm{FeSO}_{4} 100 \mathrm{~g}^{-}$ 1 DW) and then declined with the opening of flower (Table 6). Moreover, the trends of ferric ion-reducing activities in four flowering stages were similar to the $\mathrm{DPPH}$ radical-scavenging activities and the highest antioxidant activity at the first half stage may be attributed to higher total phenolic and flavonoid content at these stages. The average value of FRAP of four stages was $1.53 \mathrm{mmol} \mathrm{FeSO}_{4} 100 \mathrm{~g}^{-1} \mathrm{DW}$. This value was higher than those determined in some kinds of vegetable and fruit species, such as spinach (0.98 mmol FeSO $\left.4100 \mathrm{~g}^{-1}\right)$, tomato $\left(0.31 \mathrm{mmol} \mathrm{FeSO}_{4} 100 \mathrm{~g}^{-1}\right)$, grape $(0.83 \mathrm{mmol}$ $\left.\mathrm{FeSO}_{4} 100 \mathrm{~g}^{-1}\right)$, and apple $\left(0.29 \mathrm{mmol} \mathrm{FeSO}_{4} 100 \mathrm{~g}^{-1}\right)$ [36], which indicated that the male inflorescences of walnut had high ferric reducing ability. Furthermore, the present study also indicated that walnut male flowers showed significant $\mathrm{Fe}^{2+}$ chelating ability, which might reduce iron-related complications in human and thereby improved quality of life [5].

Table 6. Antioxidant activity of male inflorescence of $J$. sigillaia at four flower stages

\begin{tabular}{ccccc}
\hline $\begin{array}{c}\text { Antioxidant } \\
\text { activity }\end{array}$ & EFS & FS & PSS & LPSS \\
\hline $\begin{array}{c}\text { DPPH } \\
\text { (\% inhibition) } \\
\begin{array}{c}\text { FRAP } \\
\text { (mmol 100g }\end{array} \\
\text { DW) }\end{array}$ & $2.06 \pm 0.08 \mathrm{a}$ & $1.55 \pm 0.02 \mathrm{~b}$ & $1.30 \pm 0.01 \mathrm{c}$ & $1.20 \pm 0.02 \mathrm{~d}$ \\
\hline
\end{tabular}

Mean value \pm standard deviation ( $\mathrm{n}=3$, by duplicate). Different low letters in each line indicate the significant difference among four flower stages at $p<0.05$.

\section{Conclusions}

In present study, the contents of carbohydrate, protein, amino acids, mineral elements, AsA, phenolic and flavonoid compounds and antioxidant activities of walnut male inflorescences were investigated in four flowering stages. This study confirmed that walnut male inflorescences were a good source of protein, fiber, mineral, amino acids, phenolic and flavonoid compounds, it could be utilized as food for human consumption.

Our results suggested that flower opening degree significantly affected the contents of proximate 
composition, mineral elements, amino acids, phenolic and flavonoid, as well as the antioxidant activity. In the EFS and FS, the contents of crude protein, total amino acids, carbohydrates, antioxidants (phenolic, flavonoid and ascorbic acid) and some mineral elements, such as phosphorus, zinc and copper, were higher than the second half stage. Due to high contents of phenolic and flavonoid at EFS, the highest antioxidant activity was also observed at this stage. With the opening of flower, the higher amounts of crude fat, crude fiber and some mineral elements, such as potassium, iron, manganese, calcium and magnesium appeared. The results also showed that the antioxidant activity was strictly related to the antioxidants, including ascorbic acid, phenolic and flavonoid, and significantly decreased with the opening of flower.

To our knowledge, the present study is the first nutrimental composition research on the walnut male inflorescences, which could generate useful information for consumers and may encourage researchers to utilize walnut male flower as sources of phytochemicals. However, there are rich of bioactive compound and has high level antioxidant in walnut flower, so the toxicity should be tested to confirm their safety for use as food additives. The antioxidant mechanisms and the antiproliferative of the extracts also should be further studied to gain more application for use as natural antioxidants. In addition, more complete and effective storage methods and culinary treatments are needed due to high water content in walnut male flowers, which lead the products to deteriorate and spoil easily by microorganism and chemical reactions.

\section{Acknowledgements}

This study was supported by the Guizhou Science and Technology Major Project ([2011]6011) and The National Key Technology R\&D Program (2014BAD23B03).

\section{Competing Interests}

The authors declare that there is no conflict of interests regarding the publication of this article.

\section{References}

[1] Mlcek, J. and Rop, O., "Fresh edible flowers of ornamental plantsA new source of nutraceutical foods," Trends in Food Science \& Technology, 22. 561-569. 2011.

[2] Rop, O., Mlcek, J., Jurikova, T., Neugebauerova, J. and Vabkova, J., "Edible flowers-A new promising source of mineral elements in human nutrition,” Molecules, 17. 6672-6683. 2012.

[3] Tapia, M.I., Sánchez-Morgado, J.R., García-Parra, J., Ramírez, R., Hemández, T. and González-Gómez, D., "Comparative study of the nutritional and bioactive compounds content of four walnut (Julans regia L.) cultivars," Journal of Food Composition and Analysis, 31. 232-237. 2013.

[4] Almeida, I.F., Fernandes, E., Lima, J.L.F.C., Costa, P.C. and Bahia, M.F., "Walnut (Juglans regia) leaf extracts are strong scavengers of pro-oxidant reactive species," Food Chemistry, 106. 1014-1020. 2008.

[5] Nabavi, S.F., Ebrahimzadehma, M.A., Nabavi, S.M., Mahmoudi, M. and Keyvani, R.S., "Biological activities of Juglans regia flowers," Revista Brasileira de Farmacognosia, 21. 465-470. 2011.

[6] Ebrahimzadeh, M.A., Nabavi, S.F. and Nabavi, S.M., "Antihemolytic activity and mineral contents of Juglans regia L. flowers,” European Review for Medical and Pharmacological Sciences, 17. 1881-1883. 2013.

[7] Hosseini, S.E., Karimzadeh, K. and Vessal, M., "Effects of a hydroalcoholic extract of walnut male flowers on diabetic rats," Zahedan Journal of Research in Medical Sciences, 15. 29-32. 2013.

[8] Zhang, Y.X., Fruit growing for individual tree, China agriculture press, Beijing, 2003, 298.

[9] AOAC, Official methods of analysis, 18th ed. Association of Official Analytical Chemistry, Washington, DC, 2005.

[10] National Standard of the People's Republic of China (GB/T 5009), China State Bureau of Quality and Technical Supervision, China, 2003.

[11] Sánchez-Machado, D.I., Núñez-Gastélum, J.A., Reyes-Moreno, C. Ramírez-Wong, B. and López-Cervantes, J., "Nutritional quality of edible parts of Moringa oleifera," Food Analytical Methods, 3. 175-180. 2010.

[12] Park, S., Arasu, M.V., Lee, M.K., Chun, J.H., Seo, J.M., Lee, S.W. Al-Dhabi, N.A. and Kim, S.J., "Quantification of glucosinolates, anthocyanins, free amino acids, and vitamin $\mathrm{C}$ in inbred lines of cabbage (Brassica oleracea L.)," Food Chemistry, 145. 77-85. 2014.

[13] Conde-Hernández, L.A. and Guerrero-Beltrán, J.Á., “Total phenolics and antioxidant activity of Piper auritum and Porophyllum ruderale," Food Chemistry, 142. 455-460. 2014.

[14] Feng, S., Luo, Z.S., Zhang, Y.B., Zhong, Z. and Lu, B.Y., "Phytochemical contents and antioxidant capacities of different parts of two sugarcane (Saccharum officinarum L.) cultivars," Food Chemistry, 151. 452-458. 2014.

[15] Motamed, S.M. and Naghibi, F., "Antioxidant activity of some edible plants of the Turkmen Sahra region in northern Iran," Food Chemistry, 119. 1637-1642. 2010.

[16] Hatamnia, A.A., Abbaspour, N. and Darvishzadeh, R., "Antioxidant activity and phenolic profile of different parts of Bene (Pistacia atlantica subsp. kurdica) fruits," Food Chemistry, 145. 306-311. 2014.

[17] Chen, C.Y., Zhao, S.L., Cao, J.X., Zhang, R.Q. and Guo, J.M., "The analyses of nutritional components in flowers of Jugans regia L.," Food Science, 19. 35-37. 1998.

[18] Latif, S., Pfannstiel, J., Makkar, H.P.S. and Becker, K., “Amino acid composition, antinutrients and allergens in the peanut protein fraction obtained by an aqueous enzymatic process," Food Chemistry, 136. 213-217. 2013.

[19] Arruda, V.A.S., Pereira, A.A.S., Freitas, A.S., Barth, O.M. and Almeida-Muradian, L.B., "Dried bee pollen: B complex vitamins, physicochemical and botanical composition,” Journal of Food Composition and Analysis, 29. 100-105. 2013.

[20] Ovodova, R.G., Golovchenko, V.V., Popov, S.V., Popova, G.Y., Paderin, N.M., Shashkov, A.S. and Ovodov, Y.S., "Chemical composition and anti-inflammatory activity of pectic polysaccharide isolated from celery stalks," Food Chemistry, 114. 610-615. 2009.

[21] Grzeszczuk, M., Wesolowska, A., Jadczak, D. and Jakubowska, B., "Nutritional value of chive edible flowers," Acta Scientiarum Polonorum-hortorum Cultu, 10. 85-94. 2011.

[22] Wang, X.M., Zhang, J., Wu, L.H., Zhao, Y.L., Li, T., Li, J.Q., Wang, Y.Z. and Liu, H.G., "Amini-review of chemical composition and nutritional value of edible wild-grown mushroom from China," Food Chemistry, 151. 279-285. 2014.

[23] Aboagarib, E.A.A., Yang, R.J., Hua, X. and Siddeeg, A., "Chemical Compositions, Nutritional Properties and Volatile Compounds of Guddaim (Grewia Tenax. Forssk) Fiori Fruits," Journal of Food and Nutrition Research, 2. 187-192. 2014.

[24] Singh, G., Kawatra, A. and Sehgal, S., "Nutritional composition of selected green leafy vegetables, herbs and carrots," Plant Foods for Human Nutrition, 56. 359-364. 2001.

[25] Velisek, J., Chemie Potravin, 1st ed. OSSIS: Tabor, Czech Republic, 252-324. 2002.

[26] Shajib, T.I., Kawser, M., Mia, N., Begum, P., Bhattacharjee, L., Hossain, A., Fomsgaard, I.S. and Islam, S.N., "Nutritional composition of minor indigenous fruits: Cheapest nutritional source for the rural people of Bangladesh,” Food Chemistry, 140. 466-470. 2013.

[27] Campbell, N.A. and Reece, J.B., Biology, 1st ed. Computer Press: Brno, Czech Republic, 2006, 840-911.

[28] Pan, X.J., Zhang, W.E., Liu, W., Zhang, Z. and Peng, J., (2010) "Fatty acids and amino acids content of walnut kernels in 
Guizhou," Southwest China Journal of Agricultural Sciences, 23. 497-501. 2010.

[29] WHO/FAO, Energy and protein requirements, WHO Technical Report Series, No.522. Geneva, World Health Organization, 1973.

[30] Isabelle, M., Lee, B.L., Lim, M.T., Koh, W.P., Huang, D.J. and Ong, C.N. "Antioxidant activity and profiles of common fruits in Singapore," Food Chemistry, 123. 77-84. 2010a.

[31] Isabelle, M., Lee, B.L., Lim, M.T., Koh, W.P., Huang, D.J. and Ong, C.N. "Antioxidant activity and profiles of common vegetables in Singapore," Food Chemistry, 120. 993-1003. 2010b.

[32] Sebastian, J., Padayatty, S.J., Katz, A., Wang, Y., Eck, P., Kwon, O., Lee, J.H., Chen, S., Corpe, C., Dutta, A., Dutta, S.K. and Levine, M., "Vitamin C as an antioxidant: Evaluation of its role in disease prevention," Journal of the American College of Nutrition, 22. 18-35. 2003.
[33] Zhou, Y., Wang, W., Wang, C.Z. and Pei, D., "Research progress on polyphenols from Juglans plants," Journal of Nanjing Forestry University (Natural Sciences Edition), 37. 146-152. 2013.

[34] Kaisoon, O., Siriamornpun, S., Weerapreeyakul, N., Meeso, N., "Phenolic compounds and antioxidant activities of edible flowers from Thailand," Functional Foods, 3. 88-99. 2011.

[35] Yang, R.Y., Lin, S. and Kuo, G., "Content and distribution of flavonoids among 91 edible plant species," Asia Pacific Journal of Clinical Nutrition, 17. 275-279. 2008.

[36] Halvorsen, B.L., Holte, K., Myhrstad, W., Barikmo, I., Hvattum, E., Remberg, S.F., Wold, A.B., Haffner, K., Baugerød, H., Andersen, L.F., Moskaug, Ø., Jacobs, D.R.Jr. and Blomhoff, R., "A systematic screening of total antioxidants in dietary plants," Nutrient Requirements, 132. 461-471. 2002. 